\section{Managing functional constipation in children}

\author{
Anne Rowan-Legg; Canadian Paediatric Society, Community Paediatrics Committee
}

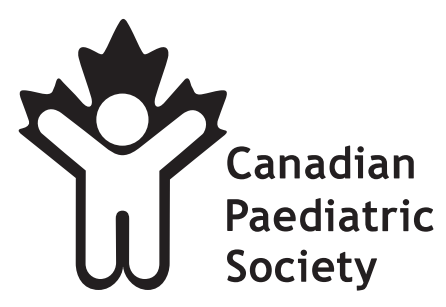

Français en page 666

\begin{abstract}
A Rowan-Legg; Canadian Paediatric Society, Community Paediatrics Committee. Managing functional constipation in children. Paediatr Child Health 2011;16(10):661-665.

Constipation is a common childhood problem, with both somatic and psychological effects. The etiology of paediatric constipation is likely multifactorial, and seldom due to organic pathology. Children benefit from prompt and thorough management of this disorder. The goal of treatment is to produce soft, painless stools and to prevent reaccumulation of feces. Education, behavioural modification, daily maintenance stool softeners and dietary modification are all important components of therapy. Fecal disimpaction may be necessary at the outset of treatment. Investigations are rarely necessary. Polyethylene glycol is a safe, effective and well-tolerated long-term treatment for constipation. Regular follow-up for children with constipation is important. Referral to a gastroenterologist should be made in refractory cases or when there is a suspicion of organic pathology.
\end{abstract}

Key Words: Constipation; Encopresis; Laxative; Paediatric

\section{La prise en charge de la constipation fonctionnelle chez l'enfant}

La constipation est un problème courant pendant l'enfance, et ses effets sont à la fois somatiques et psychologiques. L'étiologie de la constipation est probablement multifactorielle en pédiatrie, et rarement attribuable à une pathologie organique. Les enfants tirent profit d'une prise en charge rapide et approfondie de ce problème. Le traitement vise à produire des selles molles et indolores et à prévenir la réaccumulation de matières fécales. L'éducation, les changements de comportement, un traitement d'entretien quotidien aux laxatifs émollients et des modifications alimentaires constituent tous des éléments importants de la thérapie. Il peut être nécessaire de procéder à la fragmentation des fécalomes en début de traitement. Les examens exploratoires sont rarement nécessaires. Le polyéthylène glycol est un traitement à long terme sécuritaire, efficace et bien toléré de la constipation. Il est important d'assurer le suivi régulier des enfants qui font de la constipation. L'aiguillage vers un gastroentérologue est préconisé dans les cas réfractaires ou lorsqu'on craint une pathologie organique.
$\mathrm{C}$ onstipation is a common childhood complaint $(1,2)$. Despite its prevalence, it remains a challenging affliction for paediatric patients, their families and health care providers. The etiology of paediatric constipation is likely multifactorial, and is very seldom due to organic pathology. It has been shown that childhood constipation is undertreated (3). If constipation is unrecognized or inadequately treated, its effects can be far reaching - in children, it can lead to significant abdominal pain, appetite suppression, fecal incontinence with lowered self-esteem, social isolation and family disruption. Children with constipation benefit from prompt and thorough treatment intervention.

\section{DEFINITION}

Constipation is defined variably, but involves infrequent, difficult, painful or incomplete evacuation of hard stools. The term 'functional constipation' describes all children in whom constipation does not have an organic etiology. Functional constipation is commonly the result of withholding of feces in a child who wants to avoid painful defecation. Frequently, children with constipation will also experience recurrent episodes of fecal incontinence due to overflow caused by fecal impaction (known as encopresis).

The Rome II paediatric criteria for functional gastrointestinal disorders were established in 1999, and were to be used as a diagnostic aid and to provide categorization for research purposes (4). The updated Rome III criteria for functional constipation were published in $2006(5)$ :
Rome III diagnostic criteria for functional constipation (criteria fulfilled at least once per week for at least two months before diagnosis):

Must include two or more of the following in a child with a developmental age of at least four years, with insufficient criteria for the diagnosis of irritable bowel syndrome:

1. Two or fewer defecations in the toilet per week.

2. At least one episode of fecal incontinence per week.

3. History of retentive posturing or excessive volitional stool retention.

4. History of painful or hard bowel movements.

5. Presence of a large fecal mass in the rectum.

6. History of large diameter stools that may obstruct the toilet.

\section{OBJECTIVE}

The current practice point focuses on the management of functional constipation in children, rather than its differentiation from organic pathology. The reader is referred to other resources for a diagnostic discussion $(6,7)$.

\section{MANAGEMENT}

The goals in treating constipation are to produce soft, painless stools and to prevent the reaccumulation of feces. These outcomes are achieved through a combination of education, behavioural 
modification, daily maintenance stool softeners and dietary modification. Fecal disimpaction may be necessary at the outset of treatment.

Initial laboratory and radiographical investigations are not necessary unless history and examination suggest organic disease $(8,9)$.

\section{Education}

Parents and older children will benefit from a brief description of the mechanism of functional constipation. This should be the first step in treatment.

When stool enters the normal rectum, the involuntary smooth muscle of the internal anal sphincter is relaxed. The urge to defecate is signalled when the stool reaches the external anal sphincter. If the child voluntarily relaxes the external sphincter appropriately, the rectum is evacuated. If, however, the child tightens the external sphincter and the gluteal muscles, the fecal mass is pushed back into the rectal vault and the urge to defecate subsides. Parents will likely recognize examples of these characteristic withholding behaviours: squatting, rocking, stiff walking on tiptoes, crossing the legs or sitting with heels pressed against the perineum. Withholding leads to stretching of the rectum and lower colon, and retention of stool. The longer the stool remains in the rectum, the more water is removed and the harder the stool becomes, to the point of impaction. Involuntary overflow soiling then occurs around this mass of impacted stool.

Loss of control over defecation confuses the child and angers the parents, who may believe that the child is intentionally soiling his/her underwear. It is very important to remove these negative attributions, and to have parents understand that soiling is not a willful or defiant behaviour.

Two transition periods in which the developing child is particularly prone to functional constipation are at the time of toilet learning, and during the start of school (6). Toilet learning should not be a struggle, and the clinician may have a role in aiding parents to determine the child's readiness (10).

By the time a child is referred to a clinician, constipation may have been a problem for a long period. Thus, it is very important to instill hope and positivity in the frustrated child and her/his parents. Positive messaging is aided by education and a clear management plan to foster a sense of control. In addition, it is crucial to acknowledge that proper management of constipation is a longterm partnership, necessitating patience and realistic goals for improvement.

Parents often worry (but may not ask) about the potential for medications to render the bowel 'lazy' or 'addicted to laxatives'. Misconceptions must be anticipated and dispelled through education about stool softeners, which do not make the bowel contract or spasm, are absorbed minimally (if at all) from the gut, and are safe for long-term use.

\section{Fecal disimpaction}

Fecal impaction is identified by the presence of a large and hard mass in the abdomen or dilated vault filled with stool on rectal examination, and often substantiated by a history of overflow incontinence. (An abdominal radiograph is not needed to diagnose fecal impaction.) It is important to recognize the presence of fecal impaction because maintenance stool softeners can worsen overflow incontinence if the impaction is left untreated (8).

Disimpaction can be achieved by either oral or rectal medication. In a double-blind uncontrolled study, Youssef et al (11) showed that the three-day administration of polyethylene glycol (PEG) 3350 at a dose of $1 \mathrm{~g} / \mathrm{kg} /$ day to $1.5 \mathrm{~g} / \mathrm{kg} /$ day (maximum dose $100 \mathrm{~g} /$ day) successfully disimpacted $95 \%$ of children, and was well tolerated (11). Another study showed that a regimen of daily enemas for six days was equally as effective as PEG 3350 (1.5 g/kg/day) in relieving disimpaction, but may be less well tolerated (12). Highdose mineral oil has also been shown to be effective (13).

Children with severe impaction may need to be admitted to hospital or an outpatient medical unit for nasogastric lavage with PEG solution if the volume required is intolerable orally. This is usually continued until the rectal effluent is clear.

Digital disimpaction cannot be recommended based on available information, and may have harmful effects $(6,14)$.

\section{Maintenance therapy}

Once the impacted stool has been removed, the focus of the treatment should be on preventing recurrence with use of laxatives. Refer to Table 1 for a list of medications used to treat constipation. Medications have been shown to be more effective than behavioural change alone in the treatment of constipation (15). A systematic review of laxative treatments for childhood constipation has been recently published, and acknowledges the relative paucity of well-designed trials for laxatives in children and the resultant difficulty in establishing first-line therapy (16).

There is growing evidence to support the efficacy and safety of PEG 3350 in the maintenance treatment of children with constipation (17). PEG 3350 without electrolytes (Lax-A-Day [Pendopharm, Canada] or RestoraLAX [Merck Canada Inc]) is a tasteless, odourless, osmotic laxative. It is available in powder form, and dissolves well when mixed in juice or water. It is absorbed only in trace amounts from the gastrointestinal tract and, unlike other colonic lavage solutions, carries no risk of electrolyte imbalance. The effects of PEG 3350 start within the first week of treatment.

Compared with placebo, PEG 3350 was more effective in increasing defecation frequency $(18,19)$. PEG 3350 has been shown to be more effective (with increase in bowel movement frequency and decrease in fecal incontinence) than lactulose (20-23), and equally as effective as milk of magnesia, although better tolerated (24). A recent study showed no additional effect of regular enemas compared with PEG 3350 alone in children with severe constipation (25).

Dose-finding studies for PEG 3350 used starting doses of $0.4 \mathrm{~g} / \mathrm{kg} /$ day to $0.8 \mathrm{~g} / \mathrm{kg} /$ day as either a single or twice-daily dose and, when tailored to effect, a range of doses from $0.27 \mathrm{~g} / \mathrm{kg} / \mathrm{day}$ to $1.4 \mathrm{~g} / \mathrm{kg} /$ day (26), and $0.3 \mathrm{~g} / \mathrm{kg} /$ day to $1.8 \mathrm{~g} / \mathrm{kg} /$ day (27) was reported. Maintenance doses of $0.4 \mathrm{~g} / \mathrm{kg} /$ day to $1.0 \mathrm{~g} / \mathrm{kg} /$ day have been shown to be effective and well tolerated (26-28). A common reason for the lack of response to stool softening therapy is inadequate dosing; physicians should not hesitate to start PEG therapy at a higher dose of $1.0 \mathrm{~g} / \mathrm{kg}$ and then decrease as necessary.

The safety profile for PEG 3350 has been favourable. Clinical adverse effects are minor and can include bloating, flatulence, abdominal pain and loose stools $(17,18,26-28)$. In none of the aforementioned trials was PEG 3350 discontinued due to side effects related to the medication.

There is no evidence that docusate is effective in paediatric constipation. There is no evidence to recommend mineral oil in jelly form (Lansoyl [Aurium Pharma Inc, Canada]) over standard mineral oil, other than the issue of palatability. Sennosides have been shown to be inferior to lactulose, with respect to symptom control, relapse rate and side effects in two trials $(29,30)$.

With any stool softener, parents should be advised to adjust the dose according to the response, increasing the dose every two days until the child has one to two soft stools per day, or decreasing the dose if the child has loose stools. Parents should be warned that some leaking or soiling might persist at the start of treatment. Physicians should also discuss an 'emergency plan' with the 
TABLE 1

Medications for the treatment of paediatric constipation

\begin{tabular}{|c|c|c|}
\hline Laxative & Dosage & Side effects \\
\hline Lactulose & $1 \mathrm{~mL} / \mathrm{kg} /$ day $-3 \mathrm{~mL} / \mathrm{kg} /$ day in divided doses & Flatulence, abdominal cramps \\
\hline $\begin{array}{l}\text { Milk of magnesia } \\
\text { (Magnesium hydroxide) }\end{array}$ & $\begin{array}{l}1 \mathrm{~mL} / \mathrm{kg} / \text { day }-3 \mathrm{~mL} / \mathrm{kg} / \text { day of } 400 \mathrm{mg} / 5 \mathrm{~mL} \text { available as } \\
\text { liquid }\end{array}$ & $\begin{array}{l}\text { Magnesium poisoning (infants). In overdose, } \\
\text { hypermagnesemia, hypophosphatemia and secondary } \\
\text { hypocalcemia }\end{array}$ \\
\hline Polyethylene glycol 3350 & $\begin{array}{l}\text { Disimpaction: } 1 \mathrm{~g} / \mathrm{kg} / \mathrm{day}-1.5 \mathrm{~g} / \mathrm{kg} / \mathrm{day} \text { for } 3 \text { days } \\
\text { Maintenance: Starting dose at } 0.4 \mathrm{~g} / \mathrm{kg} / \text { day }-1 \mathrm{~g} / \mathrm{kg} / \text { day }\end{array}$ & Limited. Occasional abdominal pain, bloating, loose stools \\
\hline $\begin{array}{l}\text { Polyethylene glycol-electrolyte } \\
\text { solution (lavage) }\end{array}$ & $\begin{array}{l}\text { Disimpaction: } 25 \mathrm{~mL} / \mathrm{kg} / \mathrm{h} \text { (to } 1000 \mathrm{~mL} / \mathrm{h} \text { ) by nasogastric } \\
\text { tube until clear effluent } \\
\text { Maintenance: } 5 \mathrm{~mL} / \mathrm{kg} / \text { day }-10 \mathrm{~mL} / \mathrm{kg} / \text { day (older children) }\end{array}$ & $\begin{array}{l}\text { Nausea, bloating, abdominal cramps, vomiting and anal } \\
\text { irritation }\end{array}$ \\
\hline Mineral oil & $\begin{array}{l}\text { Disimpaction: } 15 \mathrm{~mL} / \text { year }-30 \mathrm{~mL} / \text { year of age (up to } \\
240 \mathrm{~mL} \text { daily) } \\
\text { Maintenance: } 1 \mathrm{~mL} / \mathrm{kg} / \text { day }-3 \mathrm{~mL} / \mathrm{kg} / \text { day } \\
<1 \text { year of age: Not recommended }\end{array}$ & $\begin{array}{l}\text { Lipid pneumonia if aspirated. } \\
\text { Theoretical interference with absorption of fat-soluble } \\
\text { substances, but no evidence }\end{array}$ \\
\hline Senna & $\begin{array}{l}\text { 2-6 years: } 2.5 \mathrm{~mL} / \text { day }-7.5 \mathrm{~mL} / \text { day } \\
\text { 6-12 years: } 5 \mathrm{~mL} / \text { day }-15 \mathrm{~mL} / \text { day }\end{array}$ & $\begin{array}{l}\text { Idiosyncratic hepatitis, melanosis coli, hypertrophic } \\
\text { osteoarthropathy, analgesic nephropathy }\end{array}$ \\
\hline Bisacodyl & $\begin{array}{l}\text { Oral: 3-12 years: } 5 \mathrm{mg} \mathrm{-} 20 \mathrm{mg} \\
\text { Rectal: <2 years: } 5 \mathrm{mg} / \text { day } \\
\quad 2-11 \text { years: } 5 \mathrm{mg} / \text { day }-10 \mathrm{mg} / \text { day }\end{array}$ & Abdominal cramping, nausea, diarrhea, proctitis (rare) \\
\hline Docusate sodium & $5 \mathrm{mg} / \mathrm{kg} /$ day divided three times a day or as a single dose & Abdominal pain, cramping, diarrhea \\
\hline Glycerin suppositories & - & None \\
\hline Phosphate enemas & $\begin{array}{l}<2 \text { years old: Not recommended } \\
>2 \text { years: } 6 \mathrm{~mL} / \mathrm{kg} \text { (up to } 135 \mathrm{~mL} \text { ) }\end{array}$ & $\begin{array}{l}\text { Risk of mechanical trauma to rectal wall } \\
\text { Abdominal distention or vomiting } \\
\text { Hyperphosphatemia, hypocalcemia }\end{array}$ \\
\hline
\end{tabular}

Adapted from references 6 and 42

parents, to be used if there is indication that impaction is recurring (eg, increasing the dose of stool softener or using suppository).

\section{Behavioural modification}

A toileting regimen that dedicates time for defecation is valuable. Most people who have normal stooling habits tend to defecate at the same time each day (8). This conditioned reflex tends to occur within $1 \mathrm{~h}$ of eating, and usually in the morning. A constipated child should have a routine scheduled toilet sitting for $3 \mathrm{~min}$ to 10 min (age dependent), once or twice a day. Ensure that the child has a footstool on which they can support their legs to effectively increase intra-abdominal pressure (valsalva). There should be no punishment for not stooling during the toileting time; praise and reward for stooling and the behaviour of toilet sitting can be offered.

It is helpful to have children and their caregivers keep a diary of stool frequency to review at the next appointment. A copy of the Bristol chart can be helpful for standardizing stool descriptions (31).

Regular physical activity can be recommended, although its role in treating constipation remains unclear (32).

\section{Dietary modification}

A balanced diet that includes whole grains, fruits and vegetables is recommended as part of the treatment of constipation in children (6).

Carbohydrates (especially sorbitol) found in prune, pear and apple juices can cause increased frequency and water content in stools (6).

Fibre intake below the minimum recommended value has been shown to be a risk factor for chronic constipation in children $(33,34)$. The American Academy of Pediatrics recommends a fibre intake of $0.5 \mathrm{~g} / \mathrm{kg} /$ day (to a maximum of $35 \mathrm{~g} /$ day) for all children (35). There is little evidence supporting fibre supplementation (above the recommended daily intake) in children with constipation. There are no published studies regarding the use of wheat dextrin (Benefiber [Novartis Consumer Health Inc, USA]) or psyllium fibre (Metamucil [Procter \& Gamble, USA]) supplements for treating childhood constipation. Adequate fluid intake must be ensured with a bulking agent such as fibre.

Although excessive milk intake can exacerbate constipation, there is insufficient evidence that eliminating it from the diet improves refractory constipation (19). For children unresponsive to adequate medical and behavioural management, consideration could be given to a time-limited trial of a cow's milk-free diet (6). Intolerance to cow's milk, particularly in children with atopy, has been associated with chronic constipation (36).

Two studies have addressed the use of probiotics in treating constipation in children $(37,38)$. In the first study, the addition of Lactobacillus rhamnosus GG was not an effective adjunct to lactulose in treating constipation (37). The second study's sample size was too small to draw any meaningful conclusion (38).

\section{CONSTIPATION IN INFANTS}

In infancy, constipation is mostly functional, but a heightened vigilance for identifying red flags suggestive of an organic disorder in this age group is necessary. It is known that breastfed infants can have greater variability than formula-fed infants in stool frequency (Some normal breastfed newborns may stool with each feeding or may not have a bowel movement any more often than every seven to 10 days.) (6). Mineral oil is contraindicated in infants because of uncoordinated swallowing and the risk of aspiration and subsequent pneumonitis. Increased intake of fluids and reducing excess cow's milk intake may be helpful for constipation in older infants (6). Recommendations to add brown sugar to formula or water for infant constipation are anecdotal and not evidence based, as well as pose a risk of caries development. Lactulose and glycerin suppositories may be used (6). Two retrospective chart reviews examining the 
safety of PEG 3350 in infants have been reported $(39,40)$. Both showed that at doses of $0.8 \mathrm{~g} / \mathrm{kg} /$ day, $\mathrm{PEG}$ was well tolerated, effective and safe in the management of constipation in infants younger than 18 months of age.

\section{FOLLOW-UP}

Regular follow-ups with ongoing support and encouragement to the child and caregivers at scheduled office visits or through phone conversations are essential. In many cases, stool softeners need to be taken for months or years to promote soft daily stools (41). Children with constipation should be treated for at least six months, and should have regular bowel movements without difficulty before considering a trial of weaning maintenance therapy. The relapse rate for constipation can be quite high, and problems with stooling may persist into adulthood (8).

\section{REFERRAL TO A GASTROENTEROLOGIST}

Consultation with a gastroenterologist should be sought when adequate therapeutic measures fail or there is a concern that organic disease exists (6). Further investigations may be warranted at this time.

\section{SUMMARY OF RECOMMENDATIONS}

- A thorough history and physical examination are required to rule out organic causes of constipation.

- Investigations (laboratory and radiography) are seldom required.

- Education is critical at the initial visit and should be regularly reinforced at subsequent visits.

- Disimpaction can be achieved with either oral or rectal medication.

- A balanced and varied diet with requisite fibre intake is recommended.

- Behavioural management should be used in conjunction with medication therapy.

- PEG 3350 is a safe, effective and well-tolerated long-term treatment for constipation.

- Regular follow-up is very important.

- Referral to a gastroenterologist should be made in refractory cases or when there is a suspicion of organic disease.

ACKNOWLEDGEMENT: This practice point was reviewed by the Canadian Paediatric Society's Nutrition and Gastroenterology Committee.

\section{REFERENCES}

1. van den Berg MM, Benninga MA, Di Lorenzo C. Epidemiology of childhood constipation: A systematic review. Am J Gastroenterol 2006;101:2401-9.

2. Shah ND, Chitkara D, Locke R, Meek PD, Talley NJ. Ambulatory care for constipation in the United States, 1993-2004. Am J Gastroenterol 2008;103:1746-53.

3. Borowitz SM, Cox DJ, Kovatchev B, Ritterband LM, Sheen J, Sutphen J. Treatment of childhood constipation by primary care physicians: Efficacy and predictors of outcome. Pediatrics 2005;115:873-7.

4. Rasquin-Weber A, Hyman PE, Cucchiara S, et al. Childhood functional gastrointestinal disorders. Gut 1999;45(Suppl 2):II60-8.

5. Rasquin A, Di Lorenzo C, Forbes D, et al. Childhood functional gastrointestinal disorders: Child/adolescent. Gastroenterology 2006;130:1527-37.
6. North American Society for Pediatric Gastroenterology, Hepatology and Nutrition. Evaluation and treatment of constipation in children: Summary of updated recommendations of the North American Society for Pediatric Gastroenterology, Hepatology and Nutrition. J Pediatr Gastroenterol Nutr 2006;43:405-7.

7. Bardisa-Ezcurra L, Ullman R, Gordon J; Guideline Development Group. Diagnosis and management of idiopathic childhood constipation: Summary of NICE guideline. BMJ 2010;340:c2585.

8. Walia R, Mahajan L, Steffen R. Recent advances in chronic constipation. Curr Opin Pediatr 2009;21:661-6.

9. Pensabene L, Buonomo C, Fishman L, Chitkara D, Nurko S. Lack of utility of abdominal $\mathrm{x}$-rays in the evaluation of children with constipation: Comparison of different scoring methods. J Pediatr Gastroenterol Nutr 2010;51:155-9.

10. Clifford C, Gorodzinsky F; Canadian Paediatric Society, Community Paediatrics Committee. Toilet learning: Anticipatory guidance with a child-oriented approach. Paediatr Child Health 2000;5(6):333-5. <http://www.cps.ca/english/statements/cp/ cp00-02.htm $>$ (Accessed on October 20, 2011).

11. Youssef NN, Peters JM, Henderson W, Shultz-Peters S, Lockhart DK, Di Lorenzo C. Dose response of PEG 3350 for the treatment of childhood fecal impaction. J Pediatr 2002;141:410-4.

12. Bekkali NL, van den Berg MM, Dijkgraaf MG, et al. Rectal fecal impaction treatment in childhood constipation: Enemas versus high doses oral PEG. Pediatrics 2009;124:e1108-15.

13. Tolia V, Lin CH, Elitsur Y. A prospective randomized study with mineral oil and oral lavage solution for treatment of faecal impaction in children. Aliment Pharmacol Ther 1993;7:523-9.

14. Gattuso JM, Kamm MA, Halligan SM, Bartram CI. The anal sphincter in idiopathic megarectum: The effects of manual disimpaction under general anesthetic. Dis Colon Rectum 1996;39:435-9.

15. Nolan T, Debelle G, Oberklaid F, Coffey C. Randomised trial of laxatives in treatment of childhood encopresis. Lancet 1991;338:523-7.

16. Pijpers MA, Tabbers MM, Benninga MA, Berger MY. Currently recommended treatments of childhood constipation are not evidence based: A systematic literature review on the effect of laxative treatment and dietary measures. Arch Dis Child 2009;94:117-31.

17. Chung S, Cheng A, Goldman RD. Polyethylene glycol 3350 without electrolytes for treatment of childhood constipation. Can Fam Physician 2009;55:481-2.

18. Thomson MA, Jenkins HR, Bisset WM, et al. Polyethylene glycol 3350 plus electrolytes for chronic constipation in children: A double blind, placebo controlled, crossover study. Arch Dis Child 2007;92:996-1000.

19. Nurko S, Youssef NN, Sabri M, et al. PEG3350 in the treatment of childhood constipation: A multicentre, double-blinded, placebo-controlled trial. J Pediatr 2008;153:254-61.

20. Voskuijl W, de Lorijn F, Verwijs W, et al. PEG 3350 (Transipeg) versus lactulose in the treatment of childhood functional constipation: A double blind, randomised, controlled, multicentre trial. Gut 2004;53:1590-4.

21. Dupont C, Leluyer B, Maamri N, et al. Double-blind randomized evaluation of clinical and biological tolerance of polyethylene glycol 4000 versus lactulose in constipated children. J Pediatr Gastroenterol Nutr 2005;41:625-33.

22. Gremse DA, Hixon J, Crutchfield A. Comparison of polyethylene glycol 3350 and lactulose for treatment of chronic constipation in children. Clin Pediatr 2002;41:225-9.

23. Candy DC, Edwards D, Geraint M. Treatment of faecal impaction with polyethylene glycol plus electrolytes $(\mathrm{PGE}+\mathrm{E})$ followed by a double-blind comparison of $\mathrm{PGE}+\mathrm{E}$ versus lactulose as maintenance therapy. J Pediatr Gastroenterol Nutr 2006;43:65-70.

24. Loening-Baucke V, Pashankar DS. A randomized, prospective, comparison study of polyethylene glycol 3350 without electrolytes and milk of magnesia for children with constipation and fecal incontinence. Pediatrics 2006;118:528-35.

25. Bongers ME, van den Berg MM, Reitsma JB, Voskuijl WP, Benninga MA. A randomized controlled trial of enemas in combination with oral laxative therapy for children with chronic constipation. Clinical Gastroenterol Hepatol 2009; 7:1069-74.

26. Pashankar DS, Bishop WP. Efficacy and optimal dose of daily polyethylene glycol 3350 for treatment of constipation and encopresis in children. J Pediatr 2001;139:428-32. 
27. Pashankar DS, Bishop WP, Loening-Baucke V. Long-term efficacy of polyethylene glycol 3350 for the treatment of chronic constipation in children with and without encopresis. Clin Pediatr 2003;42:815-9.

28. Pashankar DS, Loening-Baucke V, Bishop WP. Safety of polyethylene glycol 3350 for the treatment of chronic constipation in children. Arch Pediatr Adolesc Med 2003;157:661-4.

29. Perkin J. Constipation in childhood: A controlled comparison between lactulose and standard senna. Curr Med Res Opin 1977;4(8):540-3.

30. Sondheimer J, Gervaise E. Lubricant versus laxative in the treatment of chronic functional constipation of children: A comparative study. J Pediatr Gastroenterol Nutr 1982;1(2):223-6.

31. Lewis SJ, Heaton KW. Stool form scale as a useful guide to intestinal transit time. Scand J Gastroenterol 1997;32:920-4.

32. Inan $M$, Aydiner $C$, Tokuc B, et al. Factors associated with childhood constipation. J Paediatr Child Health 2007:43:700-6.

33. Morais MB, Vitolo MR, Aguirre AN, Fagundes-Neto U. Measurement of low dietary fiber intake as a risk factor for chronic constipation in children. J Pediatr Gastroenterol Nutr 1999;29:132-5.

34. Lee WT, Ip KS, Chan JS, Lui NW, Young BW. Increased prevalence of constipation in pre-school children is attributable to under-consumption of plant foods: A community-based study. J Pediatr Child Health 2008;44:170-5.

35. Carbohydrate and dietary fiber. In: Kleinman RE, ed. Pediatric Nutrition Handbook, 6th Edition, Community on Nutrition. American Academy of Pediatrics 2009;104

36. Iacono $\mathrm{G}$, Cavataio F, Montalto G, et al. Intolerance of cow's milk and chronic constipation in children. N Engl J Med 1998;339:1100-4.

37. Banaszkiewicz A, Szajewska H. Ineffectiveness of Lactobacillus GG as an adjunct to lactulose for the treatment of constipation in children: A double-blind, placebo-controlled randomized trial. J Pediatr 2005;146:364-9.

38. Bu LN, Chang MH, Ni YH, Chen HL, Cheng CC. Lactobacillus casei rhamnosus Lcr35 in children with chronic constipation. Pediatr Int 2007;49:485-90.

39. Loening-Baucke V, Krishna R, Pashankar DS. Polyethylene glycol 3350 without electrolytes for the treatment of functional constipation in infants and toddlers. J Pediatr Gastroenterol Nutr 2004:39;536-9.

40. Michail S, Gendy E, Preud'Homme D, Mezoff A. Polyethylene glycol for constipation in children younger than eighteen months old. J Pediatr Gastroenterol Nutr 2004:39:197-9.

41. Loening-Baucke V. Chronic constipation in children. Gastroenterology 1993;105:1557-64.

42. Lau E, ed. Drug Handbook and Formulary 2009-2010. The Hospital for Sick Children. Toronto, 2009.

\section{COMMUNITY PAEDIATRICS COMMITTEE}

Members: Minoli Amit MD (Board Representative); Carl Cummingsnal MD; Barbara Grueger MD; Mark Feldman MD (Chair); Anne RowanLegg MD

Liaison: Peter Nieman MD, Canadian Paediatric Society, Community Paediatrics Section

Consultants: Mia Lang MD; Hema Patel MD

Principal author: Anne Rowan-Legg MD

The recommendations in this document do not indicate an exclusive course of treatment or procedure to be followed. Variations, taking into account individual circumstances, may be appropriate. All Canadian Paediatric Society position statements and practice points are reviewed on a regular basis. Please consult the Position Statements section of the CPS website (www.cps.ca) for the full-text, current version. 